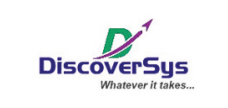

Published by DiscoverSys

\section{Ekstrak buah makasar (Brucea Javanica (L) Mer.) meningkatkan kadar enzim Superoksida Dismustase (SOD) mencit (Mus musculus) Swiss Webster jantan yang diinduksi paraquat}

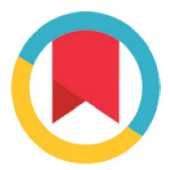

CrossMark

\author{
Maria Eka Patri Yulianti ${ }^{1 *}$
}

\title{
ABSTRACT
}

Background: Aging is a biological process where one of the contributing factors is oxidative stress due to free radicals in the body. Paraquat is an example of free radicals that are often used by oil palm plantation farmers in Bengkulu, which can trigger the aging process by reducing the enzyme Superoxide Dismutase (SOD). The provision of fruit extract of Makassar (Brucea javanica (L) Mer) contains bioactive compounds that can function as antioxidants by increasing SOD levels in the body. This study aims to prove that the fruit extract can increase the levels of SOD of male Swiss Webster mice induced by paraquat.

Methods: In vivo experimental research with randomized pretestposttest control group design was conducted on 14 Swiss Webster mice (Mus musculus) as research subjects. The research subjects were then divided into 2 groups, namely the control and the treatment group (20 mg/kgBW/day (P1) for 14 days). Data were analyzed using SPSS version 17 for Windows.

Results: The results showed that there was no significant increase in the mean of SOD levels either before $(16.97 \pm 1.45 \mathrm{U} / \mathrm{ml})$ or after $(17.07 \pm 1.89 \mathrm{U} / \mathrm{ml})$ treatment in the P0 group ( $p>0.05)$. However, in the P1 group that was given paraquat induction coupled with Makassar fruit extract at a dose of $20 \mathrm{mg} / \mathrm{kgBW} /$ day for 14 days, it showed that there was a significant increase in the mean SOD levels from $17.18 \pm 1.69 \mathrm{U} / \mathrm{ml}$ to $67.56 \pm 3.65 \mathrm{U} / \mathrm{ml}(\mathrm{p}<0.05)$.

Conclusion: Provision of Makasar fruit extract at a dose of $20 \mathrm{mg} /$ $\mathrm{kgBW} /$ day for 14 days was found to significantly increase the mean SOD levels in Swiss Webster male mice induced by paraquat.

Keywords: Macassar fruit extract, Superoxide Dismutase (SOD), Paraquat

Cite This Article: Yulianti, M.E.P. 2020. Ekstrak buah makasar (Brucea Javanica (L) Mer.) meningkatkan kadar enzim Superoksida Dismustase (SOD) mencit (Mus musculus) Swiss Webster jantan yang diinduksi paraquat. Intisari Sains Medis 11 (3): 996-999. D0I: 10.15562/ism.v11i3.743

\section{ABSTRAK}

'Departemen IImu Biologi, Fakultas Kedokteran dan IImu Kesehatan Universitas Bengkulu, Bengkulu, Indonesia

\section{*Korespondensi:}

Maria Eka Patri Yulianti;

Departemen IImu Biologi, Fakultas Kedokteran dan IImu Kesehatan Universitas Bengkulu, Bengkulu, Indonesia; mariaekapy18@gmail.com

Diterima: 01-04-2020 Disetujui: 18-08-2020 Diterbitkan: 13-10-2020
Latar Belakang: Penuaan adalah suatu proses biologi dimana salah satu faktor penyebabnya adalah stres oksidatif akibat radikal bebas yang terjadi di dalam tubuh. Paraquat merupakan salah satu contoh radikal bebas yang sering digunakan oleh petani perkebunan sawit di Bengkulu dimana dapat memicu proses penuaan melalui penurunan kadar enzim Superoksida Dismutase (SOD). Pemberian ekstrak buah makasar (Brucea javanica (L) Mer) mengandung senyawa bioaktif yang dapat berfungsi sebagai antioksidan dengan meningkatkan kadar SOD dalam tubuh. Penelitian ini bertujuan untuk membuktikan bahwa ekstrak buah makasar dapat meningkatkan kadar SOD mencit jantan swiss Webster yang diinduksi paraquat.

Metode: Penelitian eksperimental secara in vivo dengan rancangan randomized pretest-posttest control group design dilakukan terhadap 14 ekor mencit (Mus musculus) swiss Webster sebagai subjek penelitian. Subjek penelitian kemudian dibagi menjadi 2 kelompok, yaitu kelompok kontrol dan kelompok perlakuan (20 $\mathrm{mg} / \mathrm{kgBB} /$ hari (P1) selama 14 hari). Data dianalisis dengan SPSS versi 17 untuk Windows.

Hasil: Hasil penelitian menunjukan bahwa tidak terdapat peningkatan bermakna rerata kadar SOD baiksebelum $(16,97 \pm 1,45$ $\mathrm{U} / \mathrm{ml})$ atau setelah $(17,07 \pm 1,89 \mathrm{U} / \mathrm{ml})$ perlakuan pada kelompok P0 ( $p>0,05)$. Akan tetapi, pada kelompok P1 yang diberikan induksi paraquat ditambah dengan ekstrak buah makasar dengan dosis 20 $\mathrm{mg} / \mathrm{kgBB} /$ hari selama 14 hari menujukkan terdapat peningkatan secara bermakna rerata kadar SOD dari 17,18 $1,69 \mathrm{U} / \mathrm{ml}$ menjadi $67,56 \pm 3,65 \mathrm{U} / \mathrm{ml}(\mathrm{p}<0,05)$.

Kesimpulan: Pemberian ekstrak buah makasar dosis $20 \mathrm{mg} / \mathrm{kgBB}$ / hari selama 14 hari diketahui dapat meningkatkan rerata kadar SOD secara bermakna pada mencit jantan swiss Webster yang diinduksi paraquat.

\section{Kata kunci: Ekstrak buah makasar, Superoksida Dismutase (SOD), Paraquat}

Sitasi Artikel ini: Yulianti, M.E.P. 2020. Ekstrak buah makasar (Brucea Javanica (L) Mer.) meningkatkan kadar enzim Superoksida Dismustase (SOD) mencit (Mus musculus) Swiss Webster jantan yang diinduksi paraquat. Intisari Sains Medis 11 (3): 996-999. D0I: 10.15562/ism.v11i3.743 


\section{PENDAHULUAN}

Proses penuaan diketahui disebabkan oleh beberapa faktor, yaitu faktor internal (radikal bebas, hormon yang berkurang, proses glikosilasi, metilasi, apoptosis, sistem kekebalan yang menurun, genetik) dan faktor eksternal (gaya hidup tidak sehat, diet tidak sehat, kebiasaan yang salah, polusi lingkungan, stres, kemiskinan). ${ }^{1}$ Upaya dalam menghambat penuaan harus dilakukan secara dini sebelum muncul tanda dan gejala yang akan muncul. ${ }^{1}$ Proses penuaaan dapat dicegah atau diperlambat bila kita dapat menghindari faktorfaktor penyebab penuaan, sehingga kualitas hidup menjadi lebih baik. ${ }^{2}$

Salah satu faktor yang menyebabkan penuaan adalah terjadinya akumulasi kerusakan oksidatif yang disebabkan oleh tingginya radikal bebas dalam tubuh. ${ }^{3}$ Radikal bebas adalah suatu molekul reaktif dengan satu atau lebih elektron yang tidak berpasangan pada orbit terluarnya. ${ }^{4}$

Negara Indonesia yang agraris dan terjadinya peningkatan luas perkebunan kelapa sawit menyebabkan pekerja di sektor pertanian sangat tinggi dengan jumlah tenaga kerja pada tahun 2014 mencapai 40,8 juta orang dimana erat kaitannya dengan penggunaan pestisida dalam perkebunan. ${ }^{5}$ Pekerjaan ini tidak lepas dari penggunaan herbisida terutama paraquat. Paraquat merupakan senyawa kimia golongan piridina yang bersifat nonselektif. ${ }^{6}$ Senyawa ini sangat beracun dan berbahaya. ${ }^{6}$ Absorbsinya sangat cepat dengan inhalasi dan melalui usus setelah tertelan begitu pula dengan pestisida lainnya. ${ }^{7,8}$

Di Bengkulu dengan luas daerah perkebunan kelapa sawit mencapai 205.324 ha atau 34,55\% dari total luas wilayah perkebunan di Provinsi Bengkulu. ${ }^{9}$ Penggunaan herbisida meningkat seiring dengan peningkatan luas area perkebunan kelapa sawit di Provinsi Bengkulu. ${ }^{9}$ Salah satu jenis herbisida yang paling sering digunakan di Bengkulu adalah paraquat dimana angka keracunan akibat paraquat di Provinsi Bengkulu terus meningkat. ${ }^{10}$

Keracunan herbisida merupakan permasalahan kesehatan masyarakat di negara berkembang, dengan perkiraan sekitar 300.000 kematian pada regio Asia-Pasifik. ${ }^{11}$ Penggunaan paraquat yang tidak bijaksana dapat menyebabkan berbagai gangguan kesehatan seperti pada jantung, ginjal, paru, otot, kelenjar suprarenal, susunan saraf pusat dan dapat merusak hati. ${ }^{7}$

Keracunan paraquat pada dosis sedang 20-40 $\mathrm{mg} / \mathrm{kgBB}$ dalam waktu 2 hingga 8 hari didapatkan tanda-tanda kerusakan hati, ginjal dan jantung berupa ikterus, demam, sianosis, peningkatan kreatinin, bilirubin dan penurunan prothrombin. ${ }^{12}$ Paraquat menyebabkan induksi toksisitas melalui kemampuannya mempengaruhi siklus redoks dan membentuk spesies oksigen reaktif yang menyebabkan kerusakan pada jaringan. ${ }^{6,7}$ Siklus redoks merupakan reaksi utama yang bertanggung jawab terhadap toksisitas paraquat. ${ }^{6,7}$ Di dalam tubuh manusia paraquat akan direduksi oleh NADPH menjadi bentuk radikal tereduksi. ${ }^{13}$ Paraquat yang telah tereduksi akan akan mengalami reaksi dengan oksigen hingga membentuk kation paraquat dan ion superoksida. Peningkatan kadar radikal bebas akibat paraquat akan menimbulkan stres oksidatif pada sel dimana memicu terjadinya kerusakan oksidatif di dalam sel dan jaringan yang menyebabkan sel dan jaringan jaringan kehilangan fungsi dan mati. ${ }^{14}$

Indonesia kita ketahui bersama bahwa, Indonesia adalah negara yang kaya akan keanekaragaman hayati untuk pengobatan tradisional seperti buah makasar atau Brucea javanica. Studi terdahulu menunjukkan bahwa Brucea javanica memiliki sifat antioksidan terhadap radikal bebas melalui aktivitas penghambatan jalur GPa. ${ }^{15}$ Sedangkan studi lainnya menunjukkan bahwa efek antioksidan yang dimiliki oleh Brucea javanica juga berperan dalam penanganan diabetes melitus tipe 2 pada tikus. ${ }^{16}$

Paparan paraquat dapat menyebabkan penuaan (aging) karena paraquat dapat menginduksi terbentuknya radikal bebas dan menyebabkan stres oksidatif. ${ }^{17}$ Stres oksidatif ditandai tejadi penurunan kadar enzim SOD yang merupakan penanda stress oksidatif. ${ }^{17}$ Ektrak buah makasar mengandung senyawa bioaktif seperti vitamin C, flavonoid, tanin dan foliferol yang memiliki aktivitas antioksidan. ${ }^{18}$ Berkaitan dengan hal tersebut, maka penelitian ini bertujuan untuk mengetahui efek pemberian ekstrak buah makasar (Brucea Javanica (L) Mer.) meningkatkan kadar enzim Superoksida Dismustase (SOD) mencit (Mus musculus) Swiss Webster jantan yang diinduksi paraquat.

\section{METODE}

Penelitian ini adalah penelitian eksperimental, dengan menggunakan randomized pretest-posttest control group design. Subjek yang digunakan dalam penelitian ini adalah mencit (Mus musculus) swiss Webster, berumur 2-3 bulan, sehat, dengan berat badan 25-30 gram sebanyak 14 ekor yang kemudian dibagi menjadi 2 kelompok dengan masing-masing kelompok berjumlah 7 ekor mencit. Adapun kelompok mencit swiss Webster yang dimaksud adalah kelompok kontrol dimana diberikan induksi paraquat serta plasebo sebanyak $1 \mathrm{cc}$ (P0) selama 14 hari, sedangkan kelompok lainnya adalah kelompok perlakuan yang diberi paraquat dan ektrak buah makasar dosis 20mg/kgBB/hari (P1) selama 14 hari. 
Adapun parameter yang dinilai adalah kadar Superoksida Dismutase (SOD) yang berasal dari sampel darah retroorbital mencit swiss Webster dimana prinsip pemeriksaan ELISA dipergunakan pada penelitian ini. Kadar SOD diukur dalam skala $\mathrm{U} / \mathrm{ml}$ baik pada hari pemeriksaan maupun 14 hari setelah diberikan perlakuan. Data dianlisis dengan piranti lunak SPSS versi 17 untuk Windows.

\section{HASIL}

Hasil penelitian ini menunjukan bahwa terdapat peningkatan rerata kadar SOD sebelum perlakuan pada kelompok P0 secara tidak bermakna dari $16,97 \pm 1,45 \mathrm{U} / \mathrm{ml}$ menjadi $17,07 \pm 1,89 \mathrm{U} / \mathrm{ml}$ $(\mathrm{p}=0,922)$ (Tabel 1). Akan tetapi, pada kelompok P1 yang diberikan induksi paraquat dan ekstrak buah makasar dengan dosis $20 \mathrm{mg} / \mathrm{kgBB} /$ hari selama 14 hari, hasil penelitian menunjukkan bahwa terdapat peningkatan rerata kadar SOD secara bermakna dari $17,18 \pm 1,69 \mathrm{U} / \mathrm{ml}$ menjadi $67,56 \pm 3,65 \mathrm{U} / \mathrm{ml}$ pada kelompok perlakuan $(\mathrm{p}=0,000)$ (Tabel 1$)$.

\section{PEMBAHASAN}

Berdasarkan uraian hasil penelitian di atas, terjadi peningkatan kadar SOD pada mencit yang diinduksi dengan paraquat dan ekstrak buah makasar dosis 20 $\mathrm{mg} / \mathrm{kgBB} /$ hari selama 14 hari. Paraquat merupakan herbisida nitrogen yang banyak digunakan sebagai pengendali hama tanaman oleh banyak petani. ${ }^{5,19}$ Terlalu sering terpapar paraquat dapat menyebabkan keracunan paraquat melalui saluran pencernaan atau lewat kulit. ${ }^{13}$ Saat paraquat masuk melalui saluran pecernaan akan menghasilkan sensasi terbakar di mulut dan produksi mucus yang berlebihan. ${ }^{19,20}$ Selanjutnya dapat menyebabkan iritasi pada saluran gastrointestinal dikarenakan berpotensi untuk meningkatkan radikal bebas. ${ }^{19,20}$

Pada keadaan normal, anion superoksida yang dihasilkan karena paparan paraquat atau senyawa radikal bebas lainnya dikontrol oleh enzim superoksida dismutase (SOD).$^{21}$ Penelitian terdahulu menunjukkan bahwa SOD dapat dipengaruhi paraquat sudah dilakukan sejak beberapa puluh tahun sebelumnya. ${ }^{21}$ Sebagai contoh penelitian yang dilakukan oleh Wasserman B dan Block ER tahun 1978 dengan memberikan SOD

Tabel 1. Kadar SOD pada kedua kelompok penelitian baik sebelum atau setelah perlakuan selama 14 hari

\begin{tabular}{ccccc}
\hline \multirow{2}{*}{ Kelompok } & Subjek & \multicolumn{2}{c}{ Rerata nilai SOD (U/ml) } & \multirow{2}{*}{ P } \\
\cline { 3 - 4 }$(\mathbf{N = 1 4 )}$ & Sebelum & Sesudah & \\
\hline Kontrol (PO), n (\%) & $7(50,0 \%)$ & $16,97 \pm 1,45$ & $17,07 \pm 1,89$ & 0,922 \\
Perlakuan (P1), n (\%) & $7(50,0 \%)$ & $17,18 \pm 1,69$ & $67,56 \pm 3,65$ & 0,000 \\
\hline
\end{tabular}

pada tikus dewasa yang telah diinduksi paraquat selama 28 hari, menurunkan angka mortalitas dari $80 \%$ menjadi $45 \% .{ }^{22}$ Hal ini dikarenakan paraquat dapat bersifat antioksidan terhadap stress oksidatif melalui peningkatan kadar SOD dalam tubuh..$^{22,23}$

Buah makasar mengandung alkaloid (brucamarine, yatanine), glikosida (brucealin, yatanoside A dan B, kosamine), dan fenol (brucenol, bruceolic acid).$^{18}$ Bijinya mengandung brusatol dan brusein A, B, C, D, E, F, G, dan $\mathrm{H}^{18}$ Sedangkan daging buahnya diketahui mengandung minyak lemak, asam oleat, asam linoleate, asam strearat dan palmitoleate. ${ }^{18}$

Senyawa fenol dalam ekstrak buah makasar merupakan senyawa yang berpotensi sebagai antioksidan. ${ }^{18}$ Selain itu golongan senyawa yang berperan dalam aktivitas antioksidan adalah flavonoid. Flavonoid bertindak sebagai antioksidan dengan cara menangkap radikal bebas dimana terdapat berlimpah pada buah makasar (Brucea javanica). ${ }^{24}$

\section{SIMPULAN}

Berdasarkan hasil penelitian ini dapat disimpulkan bahwa ektrak buah makasar dosis $20 \mathrm{mg} / \mathrm{kgBB}$ mencit dapat meningkatkan kadar enzim superoksida dismutase (SOD) mencit swis Webster yang diinduksi paraquat. Pemberian paraquat akan megakibat terbentuknya ROS, menimbulkan stres oksidatif. Menganggu keseimbangan anti oksidan endogen kususnya SOD, sehingga kadar SOD menurun. Pemberian ektrak B. makasar yang kaya akan vitamin $\mathrm{C}$, fenol, flavonoid, tanin dapat meningkatkan kadar serum SOD mencit yang diinduksi paraquat. Kandungan senyawa aktif ini,dapat berpotensi dalam menetralisir radikal bebas dan mencegah terjadinya stres oksidatif.

\section{KONFLIK KEPENTINGAN}

Penulis menyatakan bahwa tidak terdapat konflik kepentingan dalam penulisan artikel penelitian ini.

\section{ETIKA PENELITIAN}

Penelitian ini telah mendapatkan persetujuan etik dari Komisi Etik Penggunaan Hewan dalam Penelitian dan Pendidikan Fakultas Kedokteran Hewan Universitas Udayana, Bali, Indonesia dengan nomor 388/KE-PH-Lit-2/IV/2018 sebelum penelitian berjalan.

\section{PENDANAAN}

Penulis bertanggung jawab secara mandiri dalam pendanaan penelitian ini tanpa melibatkan pihak sponsor atau sumber pendanaan lainnya. 


\section{KONTRIBUSI PENULIS}

Semua penulis memiliki kontribusi yang sama dalam penulisan laporan penelitian ini baik dari tahap penyusunan kerangka konsep, pencarian data penelitian, analisis data, hingga interpretasi data penelitian dalam bentuk publikasi ilmiah.

\section{DAFTAR PUSTAKA}

1. Harman D. The aging process. Proc Natl Acad Sci U S A. 1981;78(11):7124-7128.

2. Niccoli T, Partridge L. Ageing as a risk factor for disease. Curr Biol. 2012;22(17):R741-R752.

3. Wickens AP. Ageing and the free radical theory. Respir Physiol. 2001;128(3):379-391.

4. Barja G. Free radicals and aging. Trends Neurosci. 2004;27(10):595-600.

5. Sekiyama $M$, Tanaka $M$, Gunawan $B$, Abdoellah $O$, Watanabe C. Pesticide usage and its association with health symptoms among farmers in rural villages in West Java, Indonesia. Environ Sci. 2007;14 Suppl:23-33.

6. Saravu K, Sekhar S, Pai A, Barkur AS, Rajesh V, Earla JR. Paraquat - A deadly poison: Report of a case and review. Indian J Crit Care Med. 2013;17(3):182-184.

7. Sukumar CA, Shanbhag V, Shastry AB. Paraquat: The Poison Potion. Indian J Crit Care Med. 2019;23(Suppl 4):S263-S266.

8. Muliarta M, Tirtayasa K, Prabawa PY, Wiryadana KA. Tamarillo Consumption Associated with Increased Acetylcholinesterase Activity and Improved Oxidative Stress Markers in Farmers Exposed to Daily Pesticiderelated Activities in Baturiti, Bali, Indonesia. Open Access Macedonian Journal of Medical Sciences. 2020;8(E):244250.

9. Iskandar, Utama SP, Barchia MF. Analisis Keberlanjutan Pengelolaan Perkebunan Kelapa Sawit Pola Inti-Plasma Di PT. Bio Nusantara Teknologi Kabupaten Bengkulu Tengah. Naturalis. 2018;7(1):1-8.

10. Wibawa W, Sugandi D. Herbisida Efektif, Efisien Dan Ramah Lingkungan Untuk Pengendalian Gulma Pada Perkebunan Kelapa Sawit Rakyat Di Provinsi Bengkulu. Balai Pengkajian Teknologi Pertanian (BPTP) Bengkulu. 2012.

11. Ghosh S, Singh A, Dewan H, Walia G, Bansal A. Herbicide poisoning: A diagnostic challenge. Indian J Crit Care Med. 2012;16(1):52-54.
12. Robertus Y, Anastasyah L, Tanoyo Y. Efek Siklofosfamid dan Steroid untuk penanganan Keracunan Parakuat. Journal Indonesian Medical Association. 2012;62(1):66-70.

13. Bismuth C, Garnier R, Baud FJ, Muszynski J, Keyes C. Paraquat poisoning. An overview of the current status. Drug Saf. 1990;5(4):243-251.

14. Blanco-Ayala T, Andérica-Romero AC, Pedraza-Chaverri $\mathrm{J}$. New insights into antioxidant strategies against paraquat toxicity. Free Radic Res. 2014;48(6):623-640.

15. Ablat A, Mohamad J, Awang K, Shilpi JA, Arya A. Evaluation of antidiabetic and antioxidant properties of Brucea javanica seed. ScientificWorldJournal. 2014;2014:786130.

16. Ablat A, Halabi MF, Mohamad J, Hafiz M, Hasnan H, Hazni $\mathrm{H}$, et al. Antidiabetic effects of Brucea javanica seeds in type 2 diabetic rats. BMC Complement Altern Med. 2017;17(1):94.

17. Wiemer M, Osiewacz HD. Effect of paraquat-induced oxidative stress on gene expression and aging of the filamentous ascomycete Podospora anserina. Microb Cell. 2014;1(7):225-240.

18. Zhao L, Li C, Zhang Y, Wen Q, Ren D. Phytochemical and biological activities of an anticancer plant medicine: Brucea javanica. Anticancer Agents Med Chem. 2014;14(3):440458.

19. Bromilow RH. Paraquat and sustainable agriculture. Pest Manag Sci. 2004;60(4):340-349.

20. Suntres ZE. Role of antioxidants in paraquat toxicity. Toxicology. 2002;180(1):65-77.

21. Black AT, Gray JP, Shakarjian MP, Laskin DL, Heck DE, Laskin JD. Increased oxidative stress and antioxidant expression in mouse keratinocytes following exposure to paraquat. Toxicol Appl Pharmacol. 2008;231(3):384-392.

22. Wasserman B, Block ER. Prevention of acute paraquat toxicity in rats by superoxide dismutase. Aviat Space Environ Med. 1978;49(6):805-809.

23. Pisoschi AM, Pop A. The role of antioxidants in the chemistry of oxidative stress: A review. Eur J Med Chem. 2015;97:55-74.

24. Kim JA, Lau EK, Pan L, De Blanco EJ. NF-kappaB inhibitors from Brucea javanica exhibiting intracellular effects on reactive oxygen species. Anticancer Res. 2010;30(9):32953300 .

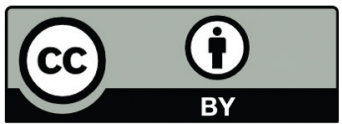

This work is licensed under a Creative Commons Attribution 